\title{
ANALISIS IMPLEMENTASI PENDIDIKAN KARAKTER DI SEKOLAH DASAR NEGERI 115 PEKANBARU
}

\author{
Zaka Hadikusuma Ramadan
}

Surel: zakahadi@edu.uir.ac.id

\begin{abstract}
This study aims to describe; 1) the implementation of character education values in terms of the planning and implementation process in SD Negeri 115 Pekanbaru; 2) behavior of SD Negeri 115 Pekanbaru students in applying the values of religious character, honesty, diligence, discipline, and care / responsibility. This study uses a quantitative descriptive approach with survey methods. The location of this research was carried out at the SD Negeri 115 Pekanbaru City, having its address at Jalan Handayani, Sidomulyo Timur Mapoyan Pekanbaru, Riau Province. Data collection techniques in this study are; 1) interview; 2) observation; 3) questionnaire (questionnaire); and 4) documentation. The results showed that the tendency of the implementation of character education values in the good category was 8 people $(12.7 \%)$, while in the sufficient category there were 46 people (73.0\%) and in the poor category 9 people (14.3\%). So it can be concluded that the tendency of the implementation of the value of character education in SDN 115 Pekanbaru is in the sufficient category.
\end{abstract}

Keywords: Character education, Implementation, SDN 115 Pekanbaru

\begin{abstract}
ABSTRAK
Penelitian ini bertujuan untuk mendeskripsikan; 1) implementasi nilai-nilai pendidikan karakter ditinjau dari proses perencanaan dan pelaksanaan di SD Negeri 115 Pekanbaru; 2) perilaku siswa SD Negeri 115 Pekanbaru dalam menerapkan nilai karakter religius, jujur, tekun, disiplin, dan peduli/tanggungjawab. Penelitian ini menggunakan pendekatan deskriptif kuantitatif dengan metode survei. Lokasi penelitian ini dilakukan di SD Negeri 115 Kota Pekanbaru yang beralamat di Jalan Handayani, Sidomulyo Timur Mapoyan Pekanbaru Provinsi Riau. Teknik pengumpulan data dalam penelitian ini adalah; 1) wawancara; 2) observasi; 3) kuesioner (angket); dan 4) dokumentasi. Hasil penelitian menunjukkan bahwa kecenderungan implementasi nilai pendidikan karakter pada kategori baik sebanyak 8 orang $(12,7 \%)$, sementara pada kategori cukup sebanyak 46 orang $(73,0 \%)$ dan pada kategori kurang sebanyak 9 orang $(14,3 \%)$. Jadi dapat disimpulkan bahwa kecenderungan implementasi nilai pendidikan karakter di SDN 115 Pekanbaru dalam kategori cukup.
\end{abstract}

Kata kunci: Pendidikan karakter, Implementasi, SDN 115 Pekanbaru.

\section{PENDAHULUAN}

Pendidikan karakter yang mulai ditanamkan sejak dini sebagai usaha aktif untuk membentuk kebiasaan baik, perlu ditanamkan terus menerus/berkelanjutan. Thomas
Lickona menjelaskan bahwa karakter terdiri atas tiga bagian yang saling terkait, yaitu pengetahuan tentang moral (moral knowing), perasaan tentang moral (moral feeling) dan perilaku bermoral (moral behavior). 
Artinya, manusia yang berkarakter adalah individu yang mengetahui tentang kebaikan (knowing the good), menginginkan dan mencintai kebaikan (loving the good), dan melakukan kebaikan (acting the good). Pendidikan karakter memiliki esensi dan makna yang sama dengan perilaku, moral atau pendidikan akhlak. Tujuannya adalah membentuk pribadi anak, supaya menjadi pribadi yang baik, jika di masyarakat menjadi warga yang baik, dan jika dalam kehidupan bernegara menjadi warga negara yang baik. Selain itu, dengan mendidik anakanak dalam bidang nilai-nilai yang dimulai sejak usia dini, bersifat continue serta sinergis antara pendidikan keluarga, sekolah, dan masyarakat, karena sesungguhnya pendidikan informal yang ditanamkan oleh orangtua di dalam keluarga dan masyarakat lebih berorientasi pada nilai-nilai keagamaan dan perilaku anak.

Permasalahannya selama ini nilai-nilai pendidikan karakter di sekolah hanya sebatas indoktrinatif dan dalam pengetahuan atau teori saja, dan belum pada taraf penanaman dan pelaksanaan dalam perilaku nyata sehari-hari. Zuchdi (2012: 5) menyatakan bahwa pendidikan moral yang bersifat indoktrinatif hanya cukup untuk membendung terjadinya perilaku menyimpang dari norma kemasyarakatan, namun hal tersebut tidak mungkin dapat membentuk pribadi-pribadi yang memiliki kemandirian dalam keputusan moral.
Hal tersebut sejalan dengan Muslich (2011: 85), yang menyatakan bahwa pendidikan karakter tidak boleh hanya menyentuh pada tingkatan pengenalan norma atau nilai-nilai saja, tapi juga harus pada tingkatan internalisasi dan tindakan nyata dalam kehidupan sehari-hari

Sekolah Dasar Negeri 115 Pekanbaru merupakan sekolah yang menerapkan Kurikulum 2013. Yang mana kurikulum 2013 merupakan kurikulum yang menekankan kepada pendidikan karakter. Berdasarkan kategori itulah peneliti ingin menggali bagaimana implementasi pendidikan karakter di SD Negeri 115 Pekanbaru. Tentunya sebagai praktisi pendidikan dalam hal ini dosen, memandang betapa pentingnya pendidikan karakter diterapkan sejak dini dalam pembelajaran di sekolah. Melihat fenomena yang terjadi saat ini tentunya menjadi perhatian khusus bagaiman meningkatkan kembali karakter siswa sehingga tidak terlepas dari jati diri bangsa Indonesia. Hal ini juga diperkuat dengan pernyataan Zaka Hadikusuma (2017) jika menghendaki pendidikan karakter dapat berhasil maka pelaksanaannya harus dimulai sejak masa kanakkanak dan usia SD.

Tujuan dari penelitian ini adalah; 1) mendeskripsikan implementasi nilai-nilai pendidikan karakter ditinjau dari proses perencanaan dan pelaksanaan di SD Negeri 115 Pekanbaru; dan 2) mendeskripsikan perilaku siswa SD Negeri 115 Pekanbaru dalam menerapkan nilai karakter religius, 
jujur, tekun, disiplin, dan peduli/tanggungjawab.

\section{METODE PENELITIAN}

Dilihat dari tujuannya, jenis penelitian yang digunakan adalah penelitian deskriptif kuantitatif dengan metode survei. Lokasi penelitian ini dilakukan di SD Negeri 115 Kota Pekanbaru yang beralamat di Jalan Handayani, Kelurahan Sidomulyo Timur Kecamatan Marpoyan Damai Kota Pekanbaru Provinsi Riau. Metode pengambilan sampel yang digunakan adalah purposive sampling. Sampel yang digunakan dalam penelitian ini adalah kepala sekolah sebanyak 1 orang, Waka Kurikulum sebanyak 1 orang, guru yang ditunjuk langsung oleh Kepala Sekolah yaitu guru Wali Kelas VB sebanyak 1 orang, serta siswa kelas VA sebanyak 32 orang, dan siswa kelas VB sebanyak 31 orang. Alasan dipilihnya siswa kelas $\mathrm{V}$ sebagai sampel dalam pengisian angket adalah, pada tingkatan ini siswa kelas $\mathrm{V}$ merupakan siswa tertua dalam pendidikan SD (Sekolah Dasar) setelah kelas VI. Selain itu, siswa kelas V sudah mendapatkan pendidikan karakter sekurangkurangnya selama lima tahun. Oleh karenanya, secara otomatis para siswa tersebut juga lebih tanggap dan mudah untuk diajak berkomunikasi. Instrumen dalam penelitian ini berupa pedoman wawancara (kepala sekolah dan guru), dan angket yang berisi seperangkat pertanyaan yang harus dijawab dan diisi oleh responden (siswa), instrumen penelitian yang digunakan, berupa angket tertutup berisi daftar pertanyaan dengan beberapa alternative jawaban yang didasarkan pada skala Likert. Analisis data dilakukan dengan 2 cara, kuantitatif dan kualitatif.

Data yang telah dianalisis tersebut kemudian diinterpretasikan dalam bentuk deskriptif atau narasi. Berikut merupakan tabel tentang presentase deskripsi.

Tabel 1. Persentase Deskripsi

\begin{tabular}{l|l}
\hline $\begin{array}{c}\text { Rentang } \\
\text { Presentase }\end{array}$ & \multicolumn{1}{c}{ Kualitas } \\
\hline $\mathrm{X} \geq \mathrm{M}+\mathrm{SD}$ & Baik \\
\hline $\mathrm{M}-\mathrm{SD} \leq \mathrm{X}$ & Cukup \\
$<\mathrm{M}+\mathrm{SD}$ & \\
\hline $\mathrm{X}<\mathrm{M}-\mathrm{SD}$ & Rendah/Kurang \\
\hline
\end{tabular}

Sedangkan data yang diperoleh melalui wawancara, dokumentasi, dan pengamatan langsung dengan pendekatan deskriptif yang mengedepankan kebermaknaan data akan dianalisis dan diinterpretasikan dengan menggambarkan data apa adanya yang ada di lapangan mengenai implementasi nilai-nilai pendidikan karakter di SD Negeri 115 Pekanbaru.

\section{HASIL PENELITIAN DAN PEMBAHASAN}

Berdasarkan hasil wawancara dan dokumentasi menunjukkan bahwa proses implementasi pendidikan karakter di SDN 115 Pekanbaru dilaksanakan mulai dari awal ketika siswa memasuki pintu gerbang 
sekolah. SDN 115 Pekanbaru tampak memiliki komitmen yang tinggi dalam menanamkan dan mengembangkan nilai-nilai karakter. Hal tersebut terlihat dari visi dan misi sekolah, fasilitas sekolah yang baik, dan kondisi sekolah yang cukup rapi, bersih, dan nyaman. Fasilitas seperti ruang kelas dan sarana prasarana lainnya juga cukup memadai. Hal ini tentunya dapat mendukung dalam proses implementasi nilai pendidikan karakter di sekolah. Berikut merupakan penjelasan proses implementasi nilai-nilai karakter di SDN 115 Pekanbaruyang diperoleh dari wawancara dan dokumentasi.

Tabel 2. Hasil Uji Deskriptif

\begin{tabular}{|c|c|c|c|c|c|c|c|}
\hline \multicolumn{8}{|c|}{ Statistics } \\
\hline & & Implementasi & religius & jujur & tekun & disiplin & peduli \\
\hline \multirow[t]{2}{*}{$\mathrm{N}$} & Valid & 63 & 63 & 63 & 63 & 63 & 63 \\
\hline & Missing & 0 & 0 & 0 & 0 & 0 & 0 \\
\hline \multicolumn{2}{|c|}{ Mean } & 63,1429 & 11,8730 & 13,0159 & 12,6984 & 13,2063 & 12,3492 \\
\hline \multicolumn{2}{|c|}{ Median } & 64,0000 & 12,0000 & 14,0000 & 13,0000 & 13,0000 & 13,0000 \\
\hline \multicolumn{2}{|c|}{ Mode } & 69,00 & 11,00 & 14,00 & 13,00 & 13,00 & 14,00 \\
\hline \multicolumn{2}{|c|}{ Std. Deviation } & 7,62605 & 2,23961 & 1,86212 & 1,71929 & 1,66713 & 1,89361 \\
\hline \multicolumn{2}{|c|}{ Variance } & 58,157 & 5,016 & 3,467 & 2,956 & 2,779 & 3,586 \\
\hline \multicolumn{2}{|c|}{ Range } & 36,00 & 8,00 & 8,00 & 8,00 & 8,00 & 8,00 \\
\hline \multicolumn{2}{|c|}{ Minimum } & 38,00 & 7,00 & 7,00 & 7,00 & 7,00 & 7,00 \\
\hline \multicolumn{2}{|c|}{ Maximum } & 74,00 & 15,00 & 15,00 & 15,00 & 15,00 & 15,00 \\
\hline \multicolumn{2}{|c|}{ Sum } & 3978,00 & 748,00 & 820,00 & 800,00 & 832,00 & 778,00 \\
\hline
\end{tabular}

Berdasarkan tabel di atas, secara keseluruhan jumlah data yang terbaca oleh komputer atau jumlah data yang valid adalah 63 data. Untuk perilaku siswa dalam menerapkan nilai karakter, rata-ratanya (mean) adalah 63,14; nilai tengahnya (median) adalah 64,00; nilai yang sering muncul (modus) adalah 69,00; nilai maksimumnya sebesar 74,00 dan nilai minimumnya 38,00. Dimensi nilai karakter yang diukur dalam penelitian ini meliputi nilai religius, jujur, tekun, disiplin, dan peduli/tanggung jawab. Untuk nilai religius, rataratanya (mean) adalah 11,87; nilai tengahnya (median) adalah 12,00; nilai yang sering muncul (modus) adalah 11,00 ; nilai maksimumnya sebesar 15,00 dan nilai minimumnya 7,00. Sementara untuk nilai jujur, rata-ratanya (mean) adalah 13,01; nilai tengahnya (median) adalah 14,00; nilai yang sering muncul (modus) adalah 14,00; nilai maksimumnya sebesar 15,00 dan nilai minimumnya 7,00 . Pada nilai tekun, rata-ratanya (mean) adalah 12,69; nilai tengahnya (median) adalah 13,00; nilai yang sering muncul (modus) adalah 13,00; nilai maksimumnya sebesar 15,00 dan nilai minimumnya 7,00 . Dan pada nilai disiplin, rata-ratanya (mean) adalah 13,21; nilai tengahnya (median) adalah 13,00; nilai yang sering muncul (modus) adalah 13,00; nilai maksimumnya sebesar 
Zaka Hadikusuma Ramadan : Analisis Implementasi ...

15,00 dan nilai minimumnya 7,00 . Sedangkan pada nilai peduli/tanggungjawab, rata- ratanya (mean) adalah 12,35 ; nilai tengahnya (median) adalah 13,00; nilai yang sering muncul (modus) adalah 14,00; nilai maksimumnya sebesar 15,00 dan nilai minimumnya 7,00. Data implementasi nilai karakter diperoleh melalui angket yang terdiri dari 15 item yang terdiri dari nilai religius, jujur, tekun, disiplin, dan peduli/ tanggungjawab dengan jumlah responden 63 siswa.

Tabel 3. Distribusi Kategorisasi Frekuensi Nilai Karakter secara Umum

\begin{tabular}{|c|c|c|c|c|}
\hline No & \multicolumn{2}{|c|}{ Interval } & Frekuensi & Persentase \\
\hline 1 & 69,2 & 74,3 & 10 & $15.87 \%$ \\
\hline 2 & & $\begin{array}{ll}- & 69,1\end{array}$ & 26 & $41.27 \%$ \\
\hline 3 & 58,8 & $\begin{array}{ll}- & 63,9\end{array}$ & 17 & $26.98 \%$ \\
\hline 4 & 53,6 & $\begin{array}{l}-\quad 58,7 \\
\end{array}$ & 3 & $4.76 \%$ \\
\hline 5 & 48,4 & $-\quad 53,5$ & 3 & $4.76 \%$ \\
\hline 6 & 43,2 & $-48,3$ & 2 & $3.17 \%$ \\
\hline 7 & 38 & - 43,1 & 2 & $3.17 \%$ \\
\hline \multicolumn{3}{|c|}{ Jumlah } & 63 & $100.00 \%$ \\
\hline
\end{tabular}

Apabila ditampilkan dalam bentuk diagram dapat dilihat pada gambar di bawah ini.

\section{Frekuensi}

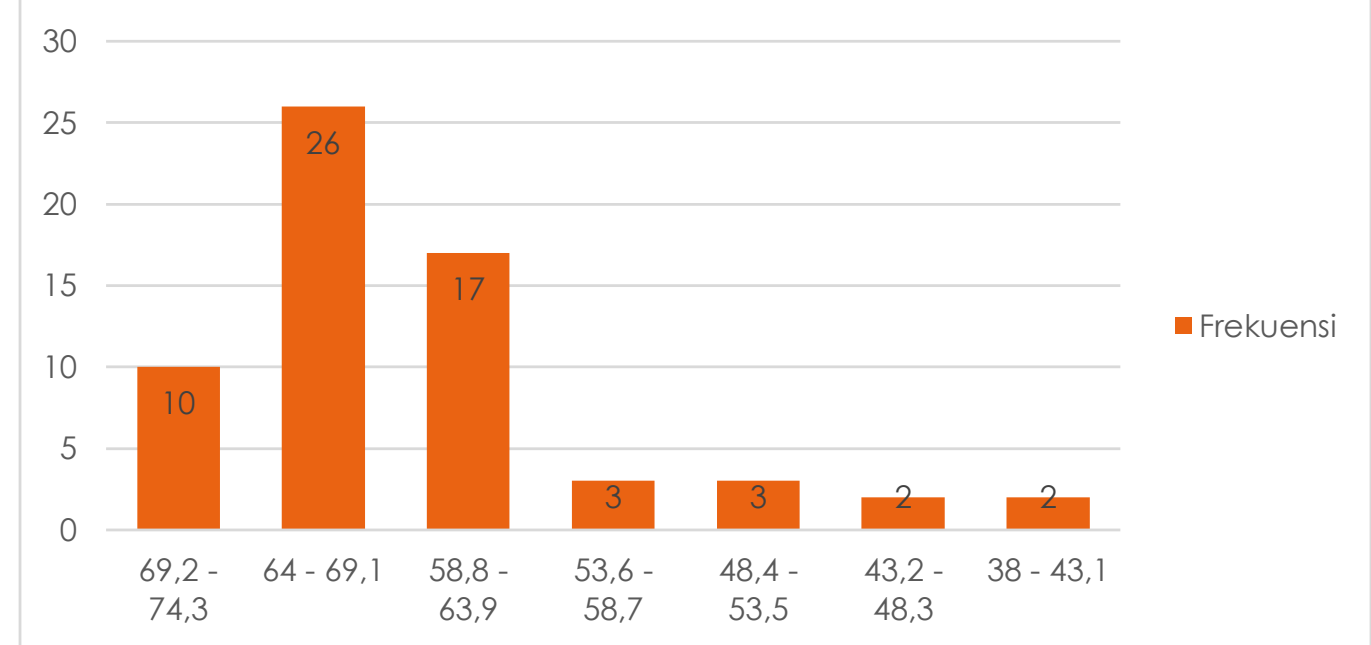

Gambar 1. Diagram Distribusi Frekuensi Nilai Karakter Siswa 
Berdasarkan tabel 14 dan gambar 6, mayoritas frekuensi nilai karakter terletak pada interval 6469.1 sebanyak 26 siswa atau $41,27 \%$ dan paling sedikit terletak pada interval 38-43.1 dan pada interval 43,2-48,3 masing-masing sebanyak 2 siswa atau $3,17 \%$. Penentuan kecenderungan variabel berdasarkan nilai mean empirik variabel implementasi nilai pendidikan karakter adalah 63,1. Standar deviasi adalah 7,6. Berdasarkan perhitungan tersebut dapat dibuat tabel distribusi kecenderungan, adapun distribusi kecenderungan variabel implementasi nilai pendidikan karakter dapat dilihat sebagai berikut:

Tabel 4. Distribusi Kategorisasi Implementasi Nilai Pendidikan Karakter

\begin{tabular}{|c|c|c|c|c|}
\hline \multirow[b]{2}{*}{ No } & \multirow[b]{2}{*}{ Skor } & \multicolumn{2}{|c|}{ Frekuensi } & \multirow[b]{2}{*}{ Kategori } \\
\hline & & Frekuensi & Persentase & \\
\hline 1 & $X \geq 70.8$ & 8 & $12.7 \%$ & Baik \\
\hline 2 & $55.5 \leq x<70.8$ & 46 & $73.0 \%$ & Cukup \\
\hline 3 & $X<55.5$ & 9 & $14.3 \%$ & Kurang \\
\hline & Total & 63 & 100,00 & \\
\hline
\end{tabular}

\section{Frekuensi}

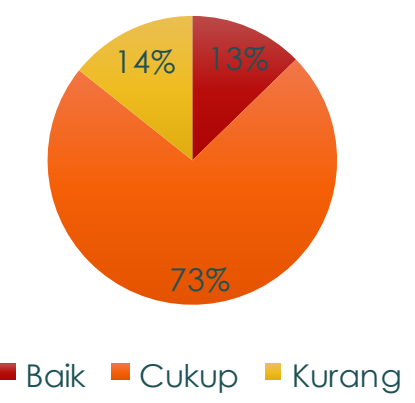

Gambar 2. Pie Chart Kecenderungan Variabel Implementasi Nilai Pendidikan Karakter

Berdasarkan tabel dan Pie Chart di atas, kecenderungan implementasi nilai pendidikan karakter pada kategori baik sebanyak 8 orang $(12,7 \%)$, sementara pada kategori cukup sebanyak 46 orang $(73,0 \%)$ dan pada kategori kurang sebanyak 9 orang
(14,3\%). Jadi dapat disimpulkan bahwa kecenderungan implementasi nilai pendidikan karakter di SDN 115 Pekanbaru dalam kategori cukup. Implementasi nilai pendidikan karakter dapat dikategori baik yaitu ketika nilai pendidikan karakter yang meliputi nilai religius, jujur, tekun, 
disiplin, dan peduli/tanggungjawab sudah dilaksanakan dengan baik oleh semua siswa SDN 115 Pekanbaru. Sementara dalam kategori cukup ketika nilai pendidikan karakter (religius, jujur, tekun, disiplin, dan peduli/ tanggungjawab) sudah dilaksanakan namun masih terdapat beberapa siswa SDN 115 Pekanbaru yang belum mempraktikkannya. Sementara dapat dikatakan dalam kategori kurang jika nilai pendidikan karakter (religius, jujur, tekun, disiplin, dan peduli/tanggungjawab) yang sudah di implementasikan di SDN 115 Pekanbaruhanya sebagian kecil siswa yang sudah mempraktikkannya dalam lingkungan sekolah maupun dirumah.

Implementasi nilai pendidikan karakter pada kategori cukup tersebut sejalan dengan upaya sekolah dalam mengimplementasikan nilai-nilai pendidikan karakter di SDN 115 Pekanbaru. Upaya sekolah dalam merencanakan, melaksanakan, dan melakukan evaluasi pendidikan akan dilakukan secara berkesinambungan (terus-menerus), karena pendidikan karakter merupakan pendidikan berkelanjutan yang mengandung makna bahwa pengembangan nilai karakter di sekolah merupakan proses panjang, dimulai dari awal peserta didik masuk sampai menyelesaikan pendidikannya. Hasil presentase kategorisasi tersebut bisa menjadi bahan evaluasi sekolah untuk mempertahakan dan lebih meningkatkan implementasi nilai pendidikan karakter agar lebih baik lagi.

\section{Pembahasan}

Perilaku siswa dalam menerapkan nilai karakter (religius, jujur, tekun, disiplin, dan peduli/tanggungjawab) sebagian besar pada kategori cukup sebanyak 46 orang $(73,0 \%)$, pada kategori baik sebanyak 8 orang $(12,7 \%)$, dan pada kategori kurang sebanyak 9 orang $(14,3 \%)$. Dengan demikian, kecenderungan perilaku nilai karakter siswa SDN 115 Pekanbaru dalam kategori cukup.

Nilai religius siswa pada kategori baik sebanyak 10 siswa atau $15,9 \%$, kategori cukup sebanyak 45 siswa atau 71,4\% dan kategori kurang sebanyak 8 siswa atau $12,7 \%$, sehingga kecenderungan perilaku nilai karakter religius siswa SDN 115 Pekanbaru adalah cukup. Nilai jujur siswa pada kategori baik sebanyak 10 siswa atau 15,9\%, kategori cukup sebanyak 42 siswa atau $66,7 \%$ dan kategori kurang sebanyak 11 siswa atau $17,5 \%$, sehingga kecenderungan perilaku nilai karakter jujur siswa SDN 115 Pekanbaru adalah cukup. Nilai tekun siswa pada kategori baik sebanyak 6 siswa atau 9,5\%, kategori cukup sebanyak 52 siswa atau $82,5 \%$ dan kategori kurang sebanyak 5 siswa atau $7,9 \%$, sehingga kecenderungan perilaku nilai karakter tekun siswa SDN 115 Pekanbaruadalah cukup. Nilai disiplin siswa pada kategori baik sebanyak 13 siswa atau 20,6\%, kategori cukup sebanyak 42 siswa atau $66,7 \%$ dan kategori kurang sebanyak 8 siswa atau $12,7 \%$, sehingga kecenderungan perilaku 
nilai karakter disiplin siswa SDN 115 Pekanbaru adalah cukup. Nilai karakter peduli/tanggungjawab siswa pada kategori baik sebanyak 4 siswa atau $6,3 \%$, kategori cukup sebanyak 50 siswaatau $79,4 \%$ dan kategori kurang sebanyak 9 siswa atau $14,3 \%$, sehingga kecenderungan perilaku nilai karakter peduli/tanggungjawab siswa SDN 115 Pekanbaruadalah cukup. Perbandingan proses implementasi kelima nilai karakter yang menjadi prioritas SDIT Hidayatullah Yogyakarta adalah sebagai berikut:

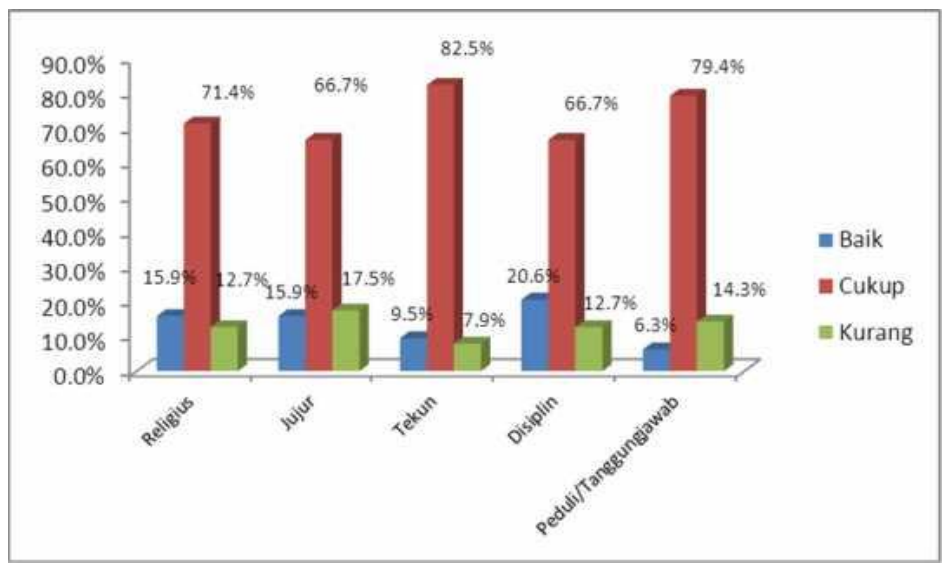

\section{Gambar 3. Perbandingan Kategori Proses Implementasi Nilai Karakter}

Berdasarkan gambar di atas menunjukkan bahwa perilaku siswa dalam menerapkan nilai karakter sebagian besar dalam kategori cukup. Nilai karakter yang paling menonjol adalah nilai karakter tekun, sedangkan nilai karakter yang paling sedikit diterapkan siswa adalah nilai karakter jujur dan disiplin. Hasil presentase kategorisasi tersebut bisa menjadi bahan evaluasi sekolah untuk mempertahankan dan lebih meningkatkan nilai karakter religius, jujur disiplin, tekun dan peduli/tanggungjawab pada peserta didiknya.

Hasil temuan lainnya menunjukkan bahwa kendala proses implementasi nilai-nilai pendidikan karakter di SDN 115 Pekanbaruantara lain: a) pihak orang tua belum seutuhnya membersamai anak seperti yang diharapkan oleh sekolah, b) pembiasaan di rumah yang tidak sejalan dengan pembiasaan di sekolah, c) lingkungan pergaulan yang tidak mendukung. Namun SDN 115 Pekanbaru juga melakukan upaya untuk mengatasi kendala dalam proses implementasi nilai-nilai pendidikan karakter meliputi: a) mengadakan kegiatan parenting school secara rutin, b) home visit jika ada hal-hal yang harus segera diselesaikan, c) mengadakan dewan kelas secara rutin, d) komunikasi wali kelas kepada orang tua secara intensif atas masalah siswa yang di alami sekolah, e) adanya pendampingan secara agama (mentoring) dan 
akademik (pendamping akademik), f) adanya tausiyah secara rutin, dan g) kedekatan guru dengan siswa untuk menggali masalah siswa.

\section{SIMPULAN}

Bedasarkan data yang diperoleh dari hasil analisis yang dilakukan maka dapat ditarik kesimpulan sebagai berikut:

- Proses Implementasi nilai-nilai pendidikan karakter di SDN 115 Pekanbaru mencakup tiga tahap yaitu perencanaan, pelaksanaan, dan evaluasi. Perencanaan merupakan tahap awal dalam melaksanakan pendidikan karakter, guru berpedoman pada buku Minhajul Muslim yang berisi mengenai nilai-nilai karakter yang harus ditanamkan pada siswa dalam kehidupan sehari-hari sesuai ajaran Islam. Selanjutnya dilakukan sosialisasi kepada seluruh elemen sekolah dan untuk menguatkan nilai-nilai karakter tersebut, pihak sekolah juga membuat tata tertib dan peraturan yang telah disepakati bersama.

- Dalam pelaksanaan pembelajaran guru tampak menekankan nilai karakter religius, jujur, tekun, disiplin dan peduli/tanggungjawab. Nilai karakter jujur dilakukan guru dengan menyisipkan nasehat kepada siswa untuk berkata jujur, saat ulangan siswa diminta untuk tidak meminta jawaban kepada teman dan apabila membeli di kantin, siswa diwajibkan membayar sesuai apa yang dibeli yang dikaitkan dengan ajaran Islam yang dikuatkan dengan Alquran dan hadist. Nilai karakter tekun juga tampak diajarkan dengan menekan kepada siswa untuk mengerjakan tugas dengan baik, memiliki catatan pelajaran yang lengkap sehingga mudah dipelajari dan menyimak dengan baik pelajaran yang disampaikan guru.

\section{DAFTAR RUJUKAN}

Agus Wibowo. 2012. Pendidikan Karakter Strategi Membangun Karakter Bangsa Berperadapan. Yogyakarta: Pustaka Pelajar.

Barnawi \& M. Arifin. 2012. Strategi \& Kebijakan Pembelajaran Pendidikan Karakter. Yogyakarta: Ar-Ruzz Media.

Darmiyati, Zuchdi. 2012. Pendidikan Karakter dalam Perspektif Teori dan Praktik. Yogyakarta: UNY Press.

Nurul, Zuriah. 2010. Pendidikan Moral \& Budi Pekerti Dalam Perspektif Perubahan Menggagas Platform Pendidikan Budi Pekerti Secara Kontekstual dan Futuristik. Jakarta: Bumi Aksara.

Ramadan, Zaka Hadikusuma. 2017. Pemahaman Kearifan Lokal di Sekolah Dasar Sebagai Suatu Cara Membentuk Karakter Siswa. Jurnal Pendidikan Guru (PIGUR), Vol. 1 No. 1, 84-93.

Saifuddin, Azwar. 2012. Penyusunan Skala Psikologi edisi 2. Yogyakarta: Pustaka Pelajar. 